\title{
Erratum to: Evolutionary history of Na,K-ATPases and their osmoregulatory role
}

\author{
Alberto G. Sáez • Encarnación Lozano • \\ Alejandro Zaldívar-Riverón
}

Published online: 4 March 2010

(C) Springer Science+Business Media B.V. 2010

Erratum to: Genetica (2009) 136:479-490

DOI: $10.1007 / \mathrm{s} 10709-009-9356-0$

This article was intended for publication in the Special Issue of Ecological Genomics.
An error of classification during peer review process has prevented its inclusion in this special issue, as it has been published earlier in Volume 136, Number 3.

The online version of the original article can be found under doi: 10.1007/s10709-009-9356-0.

A. G. Sáez (凹) · E. Lozano · A. Zaldívar-Riverón Department of Biodiversity and Evolutionary Biology, Museo Nacional de Ciencias Naturales, CSIC,

C/ José Gutiérrez Abascal 2, 28006 Madrid, Spain

e-mail: asaez@mncn.csic.es 